\title{
Antitrust in the United States and European Community: Toward a Bilateral Agreement
}

\section{INTRODUCTION}

Citing dramatically increased imports and decreased exports in the machine tool industry, semiconductor market, television market and auto parts industries, a U.S. Senator recently described America's industrial base as "in peril". ${ }^{1}$ A widely held perception ascribes this decline in American business to foreign rivals' immunity from American antitrust laws. ${ }^{2}$ Specifically, it is felt that foreign business rivals are permitted to prey on American consumers while remaining immune from the antitrust burden borne by American companies, and that this inequity renders domestic firms disadvantaged on the global market. ${ }^{3}$

These perceptions may be aggravated by the impending economic union in Europe. By December 31, 1992, twelve European Countries will join economic forces to become one of the most formidable entities in the economic world, the European Economic Community (EEC). ${ }^{4}$ Companies operating in the United States will find themselves trading among and competing with a unified market of 325 million consumers with an average per capita income of $\$ 14,500 .^{5}$ It is predicted that European businesses will emerge in 1993 larger, more efficient, and more profitable than ever before in world economic history. ${ }^{6}$ Given that the largest commercial partner of the United States is the European Community, ${ }^{7}$ it is axiomatic that changes in the European Community

1. Hearing Before the Consumer Subcomm. of the Senate Commerce, Science, and Transportation Comm., 101 Cong., 1st Sess. [hereinafter Hearings] (statement of Senator Bryan).

2. Id.

3. Id. at 2.

4. The following countries have joined the EEC: France, Italy, Germany, Belgium, the Netherlands, Luxembourg, Denmark, Greece, Ireland, Portugal, Spain, and the United Kingdom. Caterina Cregor, An Overview of the European Economic Community and Eastern Europe: Trade Opportunities, International Law, Advising Clients Trading with EEC and Eastern Europe, Indiana Continuing Legal Education Foundation (1990) [hereinafter Cregor].

5. Id.

6. Id.

7. Id. In 1989, one of every four dollars of export earnings by United States companies was earned in trade with Europe, for a total of $\$ 87$ billion. Moreover, direct world investment in the United States is led by Europe, as seven of the top ten investing countries are European. European investments in the United States are led by the United Kingdom, the Netherlands, and the Federal Republic of Germany. Export sales of EEC companies in the United States are close to $\$ 400$ billion. Id. 
will affect foreign as well as domestic operations of United States businesses.

While a strident commitment to free and open competition is one of the historical bedrocks of U.S. economic success, ${ }^{8}$ the European Community has just begun to enter the market regulation arena. Relative to institutionalized U.S. merger control policies and law, which have matured throughout over a century of practical application, merger control in the European Economic Community is a new and developing phenomenon. Member states' commitment to free trade is evidenced in their unifying treaty, which, in Article 3, proclaims, "[ $t$ ]he activities of the Community shall include... the establishment of a system ensuring that competition shall not be distorted in the Common Market. . . "9 Given that the volume of international commercial activity affecting both the United States and the European Economic Community is worth close to a trillion dollars annually, ${ }^{10}$ domestic firms on both sides of the Atlantic are potentially subject to multiple antitrust reviews which apply differing criteria.

Although the EEC Merger Control Regulation has been in force just over one year, ${ }^{11}$ Sir Leon Brittan, Vice President of the Commission of the European Communities, has already proposed a bilateral agreement between the United States and the European Community to provide for more uniform decisions in the competition field. ${ }^{12}$

Approaches to such a bilateral agreement could take innumerable shapes. This note will highlight the need for a bilateral agreement between the United States and the European Economic Community through an analysis of jurisdictional and substantive issues in the com-

8. The Sherman Act was passed over one hundred years ago, in 1890, in response to rapid industrialization and increasing concentration in the petroleum, tobacco, cotton oil, linseed oil, and paper industries. D.M. RAYBould \& Alison FirTh, Comparative Law of Monopolies 11 (1991).

9. Treaty Establishing the European Economic Community (EEC), Mar. 25, 1957, 298 U.N.T.S. 11 [hereinafter Treaty of Rome] (elipse added).

10. Cregor, supra note 4.

11. Although the origins of the EEC Merger Control Regulations date to 1973, when the Council of the European Communities considered a proposal by the Commission of the European Communities to regulate the concentrations of undertakings in the EC, Council Regulation 4064/89 of 21 December 1989 on the Control of Concentrations Between Undertakings did not enter into force until September 21, 1990. See Mark Dassesse, Selected Aspects of the European Economic Community Law on Investments and Acquisitions in Europe, 25 INT'L LAW., 375, 376 (1991) citing 1990 O.J. (L 257) 13.

12. Id. at 386 . 
petition field, with an emphasis on mergers and acquisitions. The primary focus will be on the need to build a preliminary foundation of understanding in the areas of antitrust enforcement jurisdiction, substantive merger review, and international discovery needs. These three basic foundations are proposed as fundamental prerequisites to negotiations of a bilateral agreement; while by no means exhaustive, clarification of these three areas is offered as a preliminary framework upon which to base treaty discussions in the future.

\section{Antitrust Enforcement: Jurisdictional Premises}

While the need for an agreement allocating jurisdiction between U.S. and EEC authorities in competition cases has been expressed, ${ }^{13}$ fruitful discussions on the proposal cannot be held until jurisdictional issues are viewed with uniformity by differing authorities within the same country. Treaty negotiators cannot expect to exact consensus on the allocation of jurisdiction between their respective states if they bring to the table discordant views of their own country's approach to such disputes.

\section{A. Antitrust laws and jurisdiction in the United States}

United States free market competition was recognized as an important foundation of commercial success in the United States as early as 1890 with the passage of the Sherman Act. ${ }^{14}$ Today, those principles are embodied in the U.S. antitrust laws, which solidly commit our nation to a free market economy "in which the competitive process of the market ensures the most efficient allocation of our scarce resources and the maximization of consumer welfare." 15 The primary thrust of Section 1 of the Act is to prohibit contracts, combinations, or conspiracies in restraint of trade or commerce. ${ }^{16}$ The Act supplies the basis for extraterritorial application of the law by proscribing such acts as "among the several states or with foreign nations." 17 In Section 2, the Act makes it illegal for anyone to either attempt to or to monopolize any part of the United States interstate trade or commerce. ${ }^{18}$ The Sherman Act is a criminal statute, but tends to be enforced in civil

13. Id.

14. RAYBOULD, supra note 8 .

15. 6 The Department of Justice Manual 7-1.100 (Supp. 1990-1).

16. Raybould, supra note 8 .

17. 15 U.S.C. $\$ 1$, Pub. L. No. 101-588, 4(a), 104 Stat. 2880 (1988).

18. RAYBould, supra note 8. 
proceedings brought by the Justice Department or by a State Attorney General. ${ }^{19}$ Section 73 of the Wilson Tariff Act of $1894^{20}$ prohibits an importer of goods into the United States from combining or contracting to create anti-competitive consequences in the domestic market. Section 5 of the Federal Trade Commission Act proscribes "unfair methods of competition" and "unfair or deceptive acts or practices," ${ }^{21}$ vesting enforcement authority under Section 5 with the Federal Trade Commission, although no private action exists under this Section. ${ }^{22}$

The most important antitrust statute to be passed after the Sherman Act is the Clayton Act of $1914 .^{23}$ Price discrimination by a seller of commodities of like grade and quality is proscribed, as is the conditioning of sales upon the agreement that the buyer not use or deal in products of competitors of the seller. ${ }^{24}$ The Clayton Act confers subject matter jurisdiction over a "person engaged in commerce," and includes in that definition those "corporations and associations existing under or authorized by. . . the laws of any foreign country." 25 The burden of proof under the Clayton Act is said to be lighter than the burden under the Sherman Act, the latter requiring a showing of actual anticompetitive consequences. ${ }^{26}$ In 1976, the Hart-Scott-Rodino Antitrust Improvement Act added a new Section 7(a) to the Clayton Act, requiring that plans for certain acquisitions and mergers be communicated to the

19. Id. at 13. Additionally, a private suit seeking three times the actual damages may be brought by a victim harmed by the prohibited behavior. See also supra note 16, where the the role of the Antitrust Division of the Department of Justice is established first as an enforcement agency, prosecuting civil and criminal violations under the Sherman and Clayton Acts, and secondly as an advocater, appearing before Congressional committees and federal regulatory agencies to articulate pro-competitive policies.

20. 15 U.S.C. $\$ 8$ (1982). Violation of the Act is a misdemeanor, carrying a maximum penalty of $\$ 5,000$ and/or one year in jail. Section 11 provides for seizure of the imported article. See also Barry E. Hawk, United States, Common Market, and Internatronal Antitrust: A Comparative Guide 33 (2nd ed. 1986), noting, "The antitrust provisions of the Wilson Tariff Act have received little more than passing comment from the courts. Courts have treated the Act as simply a more specific application of the Sherman Act to import restraints."

21. 15 U.S.C. $\$ 45(\mathrm{a})(1)$, Pub. L. No. 100-86, 101 Stat. 655 (1987).

22. Id.

23. 15 U.S.C. $\$ 12$, Pub. L. No. 94-435, 90 Stat. 1397 (1991).

24. Id.

25. Id. (elipse added).

26. RAYBOULD, supra note 8 , at 61 . This showing is not required in offenses under Section 1 of the Sherman Act providing for per se presumptions of anticompetitive effects. Id. 
Federal Trade Commission and the Antitrust Division of the Department of Justice. ${ }^{27}$

The United States Department of Justice Antitrust Division and the Federal Trade Commission (FTC) are responsible for enforcing the federal antitrust laws. The Federal Trade Commission Act, provides authority of the FTC in section 5, giving the FTC jurisdiction over "unfair methods of competition in or affecting commerce." 28 The FTC also has enforcement responsibility under Sections 2, 3, 7, and 8 of the Clayton Act, covering price discrimination, tying and requirements contracts and anticompetitive acquisitions of stocks or assets, and interlocking directorates respectively.

The Antitrust Division of the Department of Justice is responsible for coordinating enforcement efforts, with jurisdiction to enforce proscriptions against private restraints of trade (such as price-fixing, bidrigging, and other collusive arrangements among competitors) that unreasonably impede the free forces of the market. ${ }^{29}$ While enforcement of the Sherman Act is the primary role of the Division, it also shares concurrent jurisdiction over Section 7 of the Clayton Act (mergers) with the FTC. ${ }^{30}$

These laws and enforcement authorities are not limited in their effects to the United States. Enforcement efforts of the Antitrust Division sometimes reach foreign defendants and conduct that occurs beyond the territorial boundaries of the United States. ${ }^{31}$ The Foreign Trade

27. Id. Title I (of the Act) is procedural: it amplifies the powers of the Department of Justice given under the Antitrust Civil Process Act 1962 to issue a civil investigative demand requiring disclosure of information prior to commencing any antitrust proceedings. Title II amends the Clayton Act Section 7 by requiring premerger notification. Title III provides for actions parens patriae on behalf of persons residing in a State by the State Attorney-General in respect of violations of the Sherman Act. Id.

28. 15 U.S.C. $\$ 45(\mathrm{a})(1)(1987)$.

29. Hawk, supra note 20 , at 32 .

30. Although beyond the scope of this discussion, it may be argued that the FTC, since a legislatively mandated, independent agency, enjoys more autonomy than the DOJ Antitrust Division, which, as a part of the Executive branch, may be more susceptible to political persuasion.

31. Antitrust Enforcement Guidelines for International. Operation, supta note 15 , at $7-244.99$.

"Just as the acts of U.S. citizens in a foreign nation ordinarily are subject to the law of the country in which they take place, the acts of foreign citizens in the United States ordinarily are subject to U.S. law. The reach of the U.S. antitrust laws is not limited solely to conduct and transactions that occur within the United States, however. Conduct relating to U.S. 
Antitrust Improvement Act provides that the Sherman Act applies to anti-competitive export conduct of U.S. firms when that conduct would have a direct, substantial, and reasonably foreseeable effect on trade or commerce within the United States or on import trade or commerce. ${ }^{32}$

\section{B. Antitrust laws and jurisdiction in the EEC}

The Treaty of Rome ${ }^{33}$ establishes a common market of goods, services and agricultural products. The EEC is targeted to materialize December 31, 1992 among twelve European countries. ${ }^{34}$ Article 3 of the Treaty provides that the EEC will, among other activities, establish " a system ensuring that competition shall not be distorted in the Common Market." 35 Importantly, Community law is said to enjoy primacy over national laws of the respective member states, each of which have varying standards and interpretations of free market competition. "By contrast with ordinary international treaties, the EEC Treaty has created its own legal system, which, on the entry into force of the Treaty, became an integral part of the legal systems of the Member States and which their Courts are bound to apply." 36

Promotion of free markets and the preservation of competition within the European markets unified under the treaty fall largely under

import trade that harms consumers in the United States may be subject to the jurisdiction of the U.S. antitrust laws regardless of where such conduct occurs or the nationality of the parties involved.

Id.

32. Id. at 7-244.101. But of. Restatement (third) of the Foreign Relations Law of the United States (1987) $\$ 808-2$ (Emergency Action to Protect Domestic Producers):

Under the law of the United States, upon a finding by the International Trade Commission that increased imports are a substantial cause of serious injury or threat of serious injury to domestic producers, the President may provide relief to affected domestic parties by (a) restricting imports through tariffs or quantitative restrictions, or (b) negotiating an orderly marketing agreement.

With respect to the latter, the Trade Expansion Act of 1962, 19 U.S.C. $\int 1982$, authorizes the President to negotiate marketing agreements with foreign countries, while an agreement with private foreign producers is not within the President's authority under the Act, and such an arrangement might constitute restraint of trade in violation of the Sherman Act. Id., reporters' note 5, citing Consumers Union v. Kissinger, 506 F.2d 136 (D.C. Cir. 1974), cert. den., 421 U.S. 1004 (1975).

33. Treaty of Rome, supra note 9.

34. Cregor, supra note 4 , at 4 .

35. Treaty of Rome, supra note 9 , art. III.

36. RaYbould, supra note 8, at 184 , citing Case $6 / 64$, Coasta v. Enel, C.M.L.R. 455, 456 (1964). 
the ambit of articles 85 and 86 . Article 85 declares agreements among undertakings that substantially restrict competition within the EEC void. ${ }^{37}$ Prohibited are cartel-type arrangements between two or more undertakings having an anti-competitive object or effect, and which may affect interstate trade. ${ }^{38}$ The prevention, restriction, or distortion of competition within the common market is specifically prohibited. ${ }^{39}$ Nevertheless, the prohibition may be declared inapplicable under paragraph 3 of article 85 when the activity contributes "to the improvement of the production or distribution of goods or to the promotion of technical or economic progress. . ."

Article 86 prohibits abuse of a dominant position within the EEC, ${ }^{41}$ and unlike article 85 contains no exceptions for behavior the positive effects of which outweigh the negative. ${ }^{42}$ Article 86 prohibitions apply to abuses which occur within the Common Market, prohibiting them insofar as they may affect trade between Member States. ${ }^{43}$

37. Marc Dassesse, Selected Aspects of European Economic Community Law on Investments and Acquisitions in Europe 25 INT'L LAw. 375, 376 (1991).

38. RAYBould, supra note 8 , at 186.

39. Treaty of Rome, supra note 9 , art. 85 provides in relevant part:

1. The following shall be deemed to be incompatible with the Common Market and shall hereby be prohibited: any agreements between enterprises, any decisions by associations of enterprises and any concerted practices which are likely to affect trade between the Member States and which have as their object or result the prevention, restriction or distribution of competition within the Common Market, in particular those consisting in:

a. the direct or indirect fixing of purchase or selling prices or of any other trading conditions;

b. the limitation or control of production, markets, technical development or investment;

c. market-sharing or the sharing of sources of supply;

d. the application of parties to transactions of unequal terms in respect of equivalent supplies, thereby placing them at a competitive disadvantage; or

e. the subject of the conclusion of a contract to the acceptance by a party of additional supplies which, either by their nature or according to commercial usage, have no connection with the subject of such contract.

2. Any agreements or decisions prohibited pursuant to this Article shall be null and void.

40. Treaty of Rome, supra note 9, art. 85, 13.

41. Dassesse, supra note 38 , at 377 .

42. Id. at 376 .

43. Raybould, supra note 8 , at 187 . The full text of Article 86 provides:

To the extent to which trade between any Member States may be affected 
The sufficiency of articles 85 and 86 in their ability to protect free markets has been reviewed and found wanting. According to a European professor of law, "[articles 85 and 86] are limited and technically inadequate to do the job. For example, article 86 may not apply if there is no preexisting dominant position, and article 85 may not apply if there is no agreement between undertakings to start with." 44

Moreover, mergers of companies the effects of which reach beyond the borders of the host nation have been potentially subject to review by a number of EEC competition authorities, both at the Commission and the Member State levels. ${ }^{45}$ Perhaps arising from exigencies noted above, the EEC Merger Control Regulation, which entered into force on September 21, 1990, clearly delineates jurisdiction and authority over mergers, providing circumstances under which the Commission of the European Communities has sole jurisdiction over merger regulations, subject to review by the Court of Justice. ${ }^{46}$

The principal institutions of competition enforcement are the Council of Ministers, the Commission, the Directorate General IV, and the

thereby, action by one or more enterprises to take improper advantage of a dominant position within the Common Market or within a substantial part of it shall be deemed to be incompatible with the Common Market and shall hereby be prohibited. Such improper practices may, in particular, consist in:

a. the direct or indirect imposition of any inequitable purchase or selling prices or of any other inequitable trading conditions;

b. the limitation of production, markets or technical development to the prejudice of consumers;

c. the application to parties to transactions of unequal terms in respect of equivalent supplies, thereby placing them at a competitive disadvantage;

or

d. the subjecting of the conclusion of a contract to the acceptance, by a party, of additional supplies which, either by their nature or according to commercial usage, have no connection with the subject of such contract.

44. Dassasse, supra note 37 , at 377 .

45. Id. at 378 .

46. Id., citing Council Regulation 4064/89 of 21 December 1989 on the Control of Concentrations between Undertakings, 1990 O.J. (L 257) 33 [hereinafter Council Regulation]. The Council Regulation provides, in art 21:

1. Subject to review by the Court of Justice, the Commission shall have sole jurisdiction to take the decisions provided for in this regulation [for mergers exceeding the minimum turnover criteria laid down by the Regulation and thus having a "community dimension".]

2. No member state shall apply its national legislation on competition to any consideration [concentration] that has a community dimension. 
Court of Justice of the European Communities. ${ }^{47}$ Competition rulemaking authority rests with the Council of Ministers. ${ }^{48}$ Enforcement of EEC competition policy rests with the Commission and the Directorate General IV. ${ }^{49}$ Finally, as noted above, the Court of Justice has the authority to review decisions rendered by the Commission.

\section{Extraterritorial Jurisdiction and Customary International Law}

Were international competition regulations in accord throughout the world, and were extraterritorial jurisdictional provisions among the states clearly and historically delineated, customary international law would neatly prescribe jurisdictional and substantive disposition of international merger disputes. "It would be difficult, perhaps impossible, to find a national legal system the courts of which arbitrarily refused to apply rules of customary international law not in conflict with domestic law. . . " 50 However, there is relatively little customary international law of economic relations, ${ }^{51}$ and developing theories supporting application of domestic law to foreign transactions reflect ambiguous and sometimes conflicting approaches.

While the Sherman Act expressly applies to restraints of trade with foreign nationals, ${ }^{52}$ a federal court first held the Sherman Act applicable to conduct outside the United States where acts evidenced both an intent to and an effect on United States domestic or foreign commerce. ${ }^{53}$ Likewise, in Beguelin Import Co. v. S.A.G.L. Import Export, an action challenging an exclusive distribution agreement between a Common Market state and a non-common market state, the European Court of Justice held, rather summarily, that effects felt within the European Community sufficed to give the court jurisdiction to adjudicate the

47. 2 Barry Hawk, United States, Common Market, and International Antitrust: A Comparative Guide 3-5 (2d. ed. Supp. 1990).

48. Treaty of Rome, supra note 9 , art. 87.

49. Hawk, supra note 48 , at 4 .

50. Joseph M. Sweeney et al., The International Legal System, Cases and Materials 9 (3d ed. 1988).

51. Restatement (Third) of Foreign Relations Law of the United States 261 (Introductory Note 1987).

52. See supra note 17 and accompanying text.

53. United States v. Aluminum Co. of America, 148 F.2d 416, 443 (2d. Cir. 1945), stating that "any state may impose liabilities, even upon persons not within its allegiance, for conduct outside its borders that has consequences within its borders which the state reprehends; and these liabilities other states will ordinarily recognize." Id. (emphasis added). 
matter within article 85 of the Treaty of Rome. ${ }^{54}$ While the Beguelin Court was primarily concerned with whether the parent-subsidiary company relationship satisfied the article 85 requirement of an agreement between undertakings and whether the exclusive dealership was amenable to an exception provided in an implementing regulation, it simply concluded that the fact that one of the firms involved was a Japanese firm was of no importance so long as it was established that competition within the territory of the Community suffered and that the agreements in question affected trade between Member States. ${ }^{55}$ In this case, a Japanese firm, Oshawa, had granted exclusive distribution rights to Beguelin Imports ${ }^{56}$ for the distribution in France and Belgium of lighters bearing the Oshawa mark. The European Court of Justice found the exclusive agency agreement between a non-EEC member producer and EEC distributor prohibited by article 85 (1) when it obstructs, "de jure or de facto" the distributor's re-exportation of the products in question to other member-states, or when it prevents the product from being imported from other member-states into the protected zone and being distributed there by persons other than the concessionnaire or his customers. ${ }^{57}$

Both the United States Alcoa case and the European Court of Justice Beguelin Import case support application of domestic antitrust laws to conduct involving foreign firms pursuant to the "effects doctrine." Both approaches are consonant with international law as articulated in the Restatement of Foreign Relations, which provides that "[A] state has jurisdiction to prescribe law with respect to . . . conduct outside its territory that has or is intended to have substantial effect within its territory." 58

Within this broad parameter, however, remains a great deal of latitude for weighing when and in what circumstances domestic antitrust

54. Case 22/71, Beguelin Import Co. v S.A.G.L. Import Export, 1971 E.C.R. 949, 1972 C.M.L.R. 81.

55. Id. at 954 .

56. While the original agreement was with the Belgian parent company, the French subsidiary Beguelin Import Co. of France, took over the exclusive concession in France. The dispute arose when Beguelin sought injunctive relief to prevent a third company, G.L. Import Export, of Nice, from marketing the articles in France. G.L. Import Export responded to the injunction by asserting that the exclusive concession between Oshawa and Beguelin France violated Art. 85, as constituting an obstacle to freedom of trade within the Community. Id. at 950, 951.

57. Id. at 970 .

58. Restatement (Third) of the Foreign Relations LaW of the United States $\int 402$ (1987). 
laws will be applied to conduct occurring within the territory of another nation when the interests of both (or multiple) nations are affected. It is in this arena- where dual and equal grounds exist to support application of jurisdiction- where the most difficulty lies. It follows that a firm understanding of the varying approaches to answer this question is an absolute prerequisite to any bilateral agreement preemptively allocating jurisdiction between European Community and United States fora.

In 1984, in Timberlane Lumber v. Bank of America, the United States Court of Appeals sanctioned a seven-step balancing approach to determine whether to apply domestic antitrust laws in a private action seeking damages from an alleged conspiracy instituted and conducted in Honduras. ${ }^{59}$ While ultimately declining to exercise jurisdiction, the decision on review kept intact a seven-step weighing approach formulated in the earlier decision. ${ }^{60}$ In weighing whether to exercise jurisdiction, the Ninth Circuit Appellate Court considered: the degree of conflict with foreign law or policy, the nationality or allegiance of the parties and the locations of principal place of business, the extent to which enforcement can be expected to achieve compliance, the relative significance of effects on the United States as compared with those elsewhere, the extent of explicit purpose to harm or affect American commerce, the foreseeability of such effect, and finally, the relative importance to the violations charged of conduct within the United States as compared with conduct abroad. ${ }^{61}$

Within the year, a conflicting decision eschewing this balancing approach was handed down by another United States Court of Appeals, this time from the District of Columbia. ${ }^{62}$ In Laker Airways v. Sabena, Belgian World Airlines, a British airline operating in the United States was allegedly forced into bankruptcy by antitrust violations by other airlines, and sought remedy under U.S. antitrust laws. In a series of rather complicated maneuvers, three months after Laker Airways filed the antitrust action in the United States, several of the defendants sought and were granted an injunction by the High Court of Justice of the United Kingdom to forbid Laker Airways from proceeding with

59. Timberlane Lumber Co. v. Bank of America, 749 F.2d 1378 (9th Cir. 1984) (Timberlane II) cert. den., 472 U.S. 1032 (1985).

60. Timberlane Lumber Co. v. Bank of America, 549 F.2d 597 (9th Cir. 1976) (Timberlane I).

61. Timberlane v. Bank of America, 749 F.2d 1378, 1383-1386 (9th Cir. 1984).

62. Laker Airways Ltd. v. Sabena, Belgian World Airlines, 731 F.2d 909 (D.C. Cir. 1984) [hereinafter Laker]. 
its American antitrust claim against them. ${ }^{63}$ Fearing that the remaining two defendants would seek similar relief, Laker Airways sought and was granted injunctive relief from the U.S. District Court which barred the remaining defendants from seeking British injunction to force Laker to dismiss its suit against them. ${ }^{64}$

Then, on May 20,1983, the High Court of Justice held that the application of the American antitrust laws to companies carrying on business in the United States was not contrary to British sovereignty, with the disclaimer that in the event the English Secretary of State should declare that Britain's trading interests were negatively implicated, that holding could change. ${ }^{65}$ Such a determination was made, ${ }^{66}$ and in the next month the British Government invoked the British Protection of Trading Interests Act, ${ }^{67}$ requiring all persons conducting business in the United Kingdom to "disobey all foreign orders and cease all compliance with the foreign judicial or regulatory provisions designated by the Secretary of State." 68 The Act sought to prevent United Kingdom courts from cooperating with foreign tribunals' requests for documents, and forbade enforcement of treble damage awards or antitrust judgments as specified by the Secretary of State.

In deciding to proceed with the United States antitrust suit, the District of Columbia Circuit acknowledged that sufficient contacts existed within both the United States and England to support concurrent prescriptive jurisdiction. ${ }^{69}$ The court noted that "the mere existence of dual grounds of prescriptive jurisdiction does not oust either one of the regulating forums. Thus, each forum is ordinarily free to proceed to a judgment."70 However, in examining both the motive of the defendants in seeking injunctive relief from the British High Court, ${ }^{71}$

63. Id. at 915 .

64. Id.

65. Id. at 919 , (emphasis added).

66. Id. at 920 .

67. Protection of Trading Interests Act, 1980, ch. 11, Appendix of Record Excerpts Submitted on Behalf of Appellants Sabena and KLM at Tab 5, cited in Id. at 918 .

68. Id. at 920 .

69. Id. at 926 .

70. Id.

71. Id.

"Appellants . . . are not interested in concurrent proceedings in the courts of the United Kingdom-they want only the abandonment or dismissal of the American action against them. . [that they did not pursue a limited injunction that would have permitted the United States proceedings to 
and in reasoning that the result of granting jurisdiction to England would be to render the plaintiff without remedy, ${ }^{72}$ the Court found that it could not decline jurisdiction without totally abdicating its responsibility to protect businesses operating in the United States. Recognizing the opposition of the British Government to the right of the United States to apply its antitrust laws to British air carriers operating in the United States, the court held the antisuit injunction to be necessary to protect United States jurisdiction. ${ }^{73}$ In giving what it termed serious consideration to comity principles, the court held:

When the foreign act is inherently inconsistent with the policies underlying comity, domestic recognition could tend either to legitimize the aberration or to encourage retaliation, undercutting the realization of the goals served by comity. No nation is under an unremitting obligation to enforce foreign interests which are fundamentally prejudicial to those of the domestic forum. Thus, from the earliest times, authorities have recognized that the obligation of comity expires when the strong public policies of the forum are vitiated by the foreign act. ${ }^{74}$

While the court literally dismissed the balancing approach of Timberlane as inadequate as a basis for selecting one forum's prescriptive jurisdiction over that of another, ${ }^{75}$ it could be argued that the Laker analysis also involves an interest balancing approach, albeit of a different color. Essentially, the Laker court employed an interest balancing approach in juxtapositioning the intent behind the defendant's seeking injunctive relieve from the British tribunal and the British motive in supporting it against the interest of the United States in enforcing its

continue] indicate[s] that they are only interested in interfering with the antitrust action, and not in adjudicating the existence of an unlawful conspiracy under British law."

Id. at 930 .

72. Id.

"Appellants characterize the district court's injunction as an improper attempt to reserve to the district court's exclusive jurisdiction an action that should be allowed to proceed simultaneously in parallel forums. Actually, the reverse is true. The English action was initiated for the purpose of reserving exclusive prescriptive jurisdiction to the English courts, even through the English courts do not and can not pretend to offer the plaintiffs here the remedies afforded by the American antitrust laws."

Id.

73. Id. at 934 .

74. Id. at 937.

75. Id. at 948 . 
antitrust laws. In finding the latter outweighed other considerations, including that of comity, the court's result rested on a weighing analysis. ${ }^{76}$

Of particular importance to a discussion on the need for a bilateral jurisdiction agreement in antitrust cases are tribunals' reluctance to decide the relative merits of the antitrust laws of the United States and England. "We are in no position to adjudicate the relative importance of antitrust regulation or nonregulation to the United States and the United Kingdom. . .the judiciary. . .must weight these issues in the limited context of adversarial litigation. . . " "77 This language supports resolution of these disputes not in the judicial forum, but in the forum best equipped to weigh foreign policy proposals. Both tribunals' reluctance to formulate foreign policy with respect to antitrust matters, and their frustration in having to adjudicate in an area fraught with diplomatic complexities lends much credence to the call for a bilateral agreement in this area. In short, by refraining from deciding which nation's interests should prevail, the court declined to do by judicial fiat what arguably must be done by a bilateral treaty.

\section{Conclusion}

In visiting some of the existing jurisdictional disputes, it is clear that while they are not voluminous to date, the frustration illustrated in Laker suggests that similar jurisdictional dilemmas may become more prevalent in the future. While the United States has the benefit of over 100 years of application under the Sherman Act, the EEC's competition regulation dates back only to 1957 and the Treaty of Rome, prior to which competition was regulated individually by the respective member states. Application of domestic antitrust laws has not been limited to acts occurring in the domestic territory of either the United States or the EEC. As discussed, the textual provisions of the relevant statutes of both sides provide language which, if the other criteria are met, will allow for extraterritorial application of the law.

While principles of international comity dictate a weighing of factors prior to extraterritorial application of laws, these factors are not always dispositive of the question: with which nation should jurisdiction over this case rest? That is because a sound and objective weighing can

76. But see Deborah K. Owen and John J. Parisi, International Mergers and Joint Ventures: A Federal Trade Commission Perspective, 8 Fordham Corporate LAW InSTITUTE (B. Hawk, ed., 1991), supporting the reading of Laker as rejecting the interest balancing analysis adopted by the Ninth Circuit in the Timberlane cases.

77. Laker, 731 F.2d at $949,950$. 
result in a decision that both have equal grounds for prescriptive and enforcement jurisdiction. Specifically, parties may reside and conduct business in both jurisdictions, and the importance to each of the respective authorities in challenging or leaving intact the activity may be equal. This anomaly rests equally with the classic "effects doctrine" of international law, under which a nation has jurisdiction to enforce its laws in response to activities causing substantial effects within its territories. Again, assuming measurability, economic effects of business actions can have an impact in several national economies, thus elevating all parties to equal status in putative disputes.

A classic discussion of why judicial resolution of antitrust jurisdictional disputes on principles of international law is inadequate was provided in Laker, where tacit support for discussions between the executive branches of the governments involved was evident. The courts on both sides expressed frustration at being faced with an issue that clashes in the judicial setting due to a failure to act on the part of the executive: both were merely carrying out legislative and administrative directives of their respective countries, and both expressed perceived inadequacies of this approach.

That jurisdictional issues must play a dominant role in bilateral treaty negotiations is therefore evident. Very recently, Sir Leon Brittan, Vice President of the European Economic Community Commission, has called for such bilateral agreement between the United States and the EEC. It is hoped that discussions pursuant to this proposal will prevent a recurrence of judicial frustration of Laker magnitude in the future. Granted, consideration of ex ante jurisdiction allocation in the antitrust area will be a delicate and difficult task absent the use of a tangible set of circumstances such as is present in a judicial setting. Any attempt to determine-in advance of a dispute-which nation's laws will prevail must mix the established international doctrines of effect and comity, and leaven them with reasonableness premised upon a desire to promote economic health between the parties. Nonetheless, domestic economies depend upon reasonable certainty for their growth; before domestic businesses operating abroad can plan to accommodate competition regulations, they must know under whose jurisdiction their conduct will fall. To that end, discussions of a bilateral agreement are imperative. ${ }^{78}$

78. For a perspective limiting these concerns due to overriding practical considerations, see Owens and Parisi, supro note 76 , at 6 . (Referring to foreign parties' willingness to accommodate the U.S. Federal Trade Commission in its investigations of antitrust activity, through the use of a consent agreement, as a way to smooth entry into the U.S. business arena). 


\section{iII-Substantive Variations in Merger Control Regulations}

Part II explored conflicting approaches to assertions of domestic jurisdiction to antitrust behavior conducted by foreign actors. While the difficulty in judicial resolution of antitrust jurisdiction issues may lie, as suggested, in the reality that antitrust policy is customarily set by executive directives, an equally problematic area lies in the substantive approach of the differing jurisdictions. Part III will be devoted to an exploration of the substantive considerations that support decisions on either side of the Atlantic to either challenge or leave intact potentially monopolistic plans. Discussion in this section is limited to the area of mergers. Discussion of merger review in the United States is largely drawn from the Department of Justice Merger Guidelines; ${ }^{79}$ discussion of activity in the European Economic Community is drawn from the EEC Regulation on the Control of Concentrations Between Undertakings. ${ }^{80}$

\section{A. Product and Market Definition in the United States}

Although critical to any analysis of the possible effects of proposed or enacted mergers, there is little conformity on the identification of domestic and international geographic markets or suitable product alternatives. Thus little uniformity exists in predicting how international markets will react in response to mergers, since these predictions are ordinarily based upon market and product considerations.

In establishing the groundwork fundamental to bilateral treaty discussions in the area of antitrust, an understanding of substantive criteria used by the respective authorities to measure the legality of proposed activity is essential. ${ }^{81}$ Recalling from Part II that the United

79. Department of Justice Merger Guidelines, supra note 31, at 7-19.

80. Council Regulation, supra note 46.

81. For a discussion of United States Department of Justice antitrust analysis of mergers having international dimensions, see generally, ANTITRUST ENFORCEMENT GUIDElines for international operations, in 6 The Department of Justice Manual, supra note $\$ 15$, at 7-243. (Recognizing that some mergers present procompetitive efficiencies, the Department outlines a four step analysis to identify potential anticompetitive harms. The first step focuses on the markets in which the merged operations operate; step two focuses on other markets in which the parties are actual or possible competitors; step three assesses whether anticompetitive effects of any vertical restraints may arise from the merger [even if parties to the merger are not competitors, vertical relationships can create horizontal problems- see infra note 89]; and if steps one through three uncover significant anticompetitive risks, step four allows the Department to consider any efficiencies which would result from the transaction.) Id. at 7-244.3. 
States Department of Justice enforces antitrust policy pursuant to the Sherman Act and the Clayton Act, acquisitions and mergers are subject to section 1 of the Sherman Act ${ }^{82}$ and section 7 of the Clayton Act. ${ }^{83}$ A quick glance at the language in these Acts reveals the latitude left in determining whether activities fall into the proscriptions; virtually no guidance in determining violations is given in either Act. Accordingly, the Department of Justice's (the Department) Merger Guidelines set forth merger enforcement policies.

Any review of a proposed merger requires an analysis of market power, which is a function of the firms' product market and geographic market. The Department employs these two concepts to assess the economic impact of a proposed merger to determine whether competition will be lessened as a result of the merger. To focus the analysis on the companies involved in the review, the Department restricts its analysis to economically meaningful markets. The essential inquiry is whether the merged firms could impose and sustain price increases in those markets. ${ }^{84}$ Four factors influence whether price increases would be tolerated by the market, and therefore must be assessed in merger reviews: 1) consumers may switch to other products; 2) they may use the same product produced by other firms in other areas; 3) producers of other products could switch existing facilities to the production of the product; or 4) producers could enter into the production of the product by modifying existing facilities or constructing new facilities. ${ }^{85}$

\section{Product Market Definition}

To assess potential effects on competition of proposed mergers, the Department first measures the market for each product (or service)

82. 15 U.S.C. 1 (1982). Section 1 prohibits mergers comprising a "contract, combination. .., or conspiracy in restraint of trade"' among the several states of with foreign nations." Id.

83. 15 U.S.C. 18, Pub. L. No. 98-443, 98 Stat. 1708 (1982). Section 7 prohibits mergers if their effect "may be substantially to lessen competition, or to tend to create a monopoly." Id.

84. Merger Guidelines, supta note 15, at 7-31-32.

"Formally, a market is defined as a product or group of products and a geographic area in which it is sold such that a hypothetical, profit-maximizing firm, not subject to price regulation, that was the only present and future seller of those products in that area would impose a 'small but significant and nontransitory' increase in price above prevailing or likely future levels."

Id. at 7-32.

85. Id. at $7-32$. 
of the firms involved. ${ }^{86}$ They create as a tool for their an analysis a hypothetical firm which as the only present and future seller of those products could "profitably impose a small but significant and nontransitory" price increase. ${ }^{87}$ The inquiry here is whether there are sufficient product substitutes to enable consumers to switch to other products. If sufficient shifting occurs in the analysis, the Department adds to the product group the next best substitute for the merging firm's product, and goes through the same analysis again. This continues until a group of products is identified for which the hypothetical monopolist could impose the price increase. In general, prevailing market prices are used in the analysis; the price increase applied is five percent and it is presumed to last one year.

For purposes of this discussion, it is important to note the evidence employed by the Department in these analyses. Fundamental to an understanding of how these measurements work is the concept of using historical data as indicators of future activity. In using present market price, the Department acknowledges that changes in price may occur irrespective of the proposed merger. Namely, prices may change in an ultimate reflection of changes in product or environmental regulations. The Department's analysis of the effects of price increases is inferential, and is based on several types of circumstantial evidence, including purchasing trends, historical analyses of pricing, comparisons of characteristics of the products, and evidence of sellers' perceptions regarding whether the products are or are not substitutes. Finally, the Department includes firms in the hypothetical market which could easily convert existing productive and distributive facilities to produce and sell the relevant product within one year in response to the price increase. ${ }^{88}$

\section{Geographic Market Definition}

A similar approach is employed to define the boundaries of the geographic market which would be affected by the merger. First, the Department determines the geographic market (markets) in which that

86. Id.

87. Id.

88. Id. at 7-34-35. The manual notes that some firms could easily convert their facilities from the production of one product to another, but that these same firms may have difficulty in establishing distribution or marketing strategies in such a short time. These firms are not included in the market analysis. For a discussion of the Department's methods in identifying foreign firms whose production capacity does suggest the ability to convert to production of the product in question, see infra note 107. 
firm sells; the geographic boundaries could be atomistic or as large as the entire world. ${ }^{89}$ Again, the analysis seeks to identify the geographic area such that the hypothetical firm, as the only present or future producer or seller of the product in that area, could profitably impose a "small but significant and nontransitory" 90 price increase. If there are plenty of other firms located elsewhere which could provide the relevant product to the consumers at a similar price (building in the cost of transporting the goods into the area) the geographic area will be expanded to include those firms. The analysis continues adding firms from surrounding locations in this manner until the geographic area in which the price increase could be imposed is obtained.

In United States v. Waste Management, ${ }^{91}$ the Second Circuit cited the Merger Guidelines in their reversal of a district court's decision that a merger of two commercial waste haulers violated section 7 of the Clayton Act. ${ }^{92}$ While agreeing with the District Court's finding that the relevant geographic market was Dallas County excluding Fort Worth as part of the relevant geographic market, ${ }^{93}$ the Second Circuit nonetheless considered whether firms located outside Dallas County could successfully enter the Dallas County geographic market. ${ }^{94}$

The Second Circuit acknowledged there would be increased costs of daily travel between Fort Worth and Dallas which would not be present for Dallas-based companies, but found "no barrier to Fort Worth haulers' acquiring garage facilities in Dallas" which would permit the Fort Worth companies to keep some of their trucks stationed in Dallas. ${ }^{95}$

What Waste Management indicates with respect to the geographic market definition is that the ease of entry analysis will not be confined to those firms already or potentially operating in the court-defined geographic market. Indeed, the relative ease of entry into the trash collection business was sufficient to overcome the district court's finding of a post-merger share of $48.8 \%$ of the market, which is sufficient to establish prima facie illegality under Section 7 of the Clayton Act. ${ }^{96}$ Invoking the Merger Guidelines, (Guidelines) the Second Circuit held

89. Id. at $7-36$.

90. Id.

91. United States v. Waste Management, 743 F.2d 976 (2d Cir. 1984).

92. Id. at 982 .

93. Id. at 980 .

94. Id. at 983 (emphasis added).

95. Id.

96. Id. at 977 . 
that ease of entry is so relevant to determining how a merger will affect competition that it "may override all other factors." 97

Again, the quality of the evidence used in the geographic market definition process is critical to an accurate assessment of the merger's effects. The Department, in using the "small but significant and nontransitory" price increase as an objective guide considers historical evidence of: shipment patterns of considered firms and their competitors; evidence that consumers have shifted their purchases to sellers at different locations; differences or similarities in the price movements of the relevant product which are not caused by causative factors in the differing areas; transportation costs; local distribution costs; and excess capacity of those firms outside the merging firms' location..$^{98}$ Foreign competitors are included in the geographic market, if relevant, and market shares are assigned to them in the same manner they are assigned to domestic firms (e.g., dollar sales, shipments to the relevant market, physical production capacity, reserves, or dollar production). ${ }^{99}$

\section{Market Shares and Market Concentration}

The primary index of a firm's market power is the statistical evidence reflecting its shares of the respective market, computed by using the factors outlined above. Concentration of the market is the lead indicator of market power; controlling for other factors, the larger the percentage of total product supply controlled by one firm, the more readily the firm can restrict output in order to support a price increase in that product. ${ }^{100}$

After defining the appropriate product and geographic market, the Guidelines provide a three-tiered threshold by which to assess preliminarily the competitive effects of the proposed horizontal merger. For these purposes, mergers of firms in the same product and geographic market are considered horizontal. ${ }^{101}$ The three level approach uses the

97. Id. at 982 .

98. See supra note 15 , at 7-38.

99. Id. at 7-38. It is noted that while quotas may prohibit the increase of imports of the relevant product, those quotas may be offset by production in countries not subject to the quota. Thus quotas do not per se exclude any country from the geographic definition, and the effects of quotas are considered separately in Section 3.23 of the manual. Id. at 7-44.

100. Id.

101. Id. at 7-40. Vertical mergers involve firms at different levels of the production scheme; conglomerate mergers involve everything else. Although by definition nonhorizontal mergers will not change the HHI concentration level, they are still subject to challenge because the merger of a firm already in the market with a firm that could enter the market after the merger may affect competition as well. 
Herfindahl-Hirschman Index ( $\mathrm{HHI}$ ) to compute market concentration. ${ }^{102}$ Simply put, the HHI sums the squares of the individual market shares of all the firms identified as part of the market (including in the computations the proposed merger). Thus, a market of four firms with market shares of 40 percent, 30 percent, 20 percent, and 10 percent would yield an HHI of 3,000. $\left(40^{2}+30^{2}+20^{2}+10^{2}=3,000\right.$.) The Guidelines provide that the thresholds are characterized as unconcentrated when the $\mathrm{HHI}$ is below 1,000 , moderately concentrated when the HHI is between 1,000 and 1,800, and highly concentrated when the $\mathrm{HHI}$ is above $1,800 .^{103}$ Additionally, the Department evaluates the increase in concentration that would result from the merger. Simply, the market shares of the merging firms are multiplied, then doubled. ${ }^{104}$

Armed with these two calculations, the Department in general follows these standards: For post-merger HHI below 1000, the Department will usually not challenge the merger. For post-merger HHI between 1,000 and 1,800 the Department will not likely challenge the merger, unless the increase in $\mathrm{HHI}$ is greater than $100 .{ }^{105}$ Finally, for post-merger HHI over 1,800 and producing an increase of over 50 points, the Department will likely challenge the merger. ${ }^{106}$

However, in re Echlin Manufacturing Co., a case decided after publication of the Merger Guidelines, the Federal Trade Commission found

102. Id.

103. Id. at 7-41. Note in the hypothetical that the market is highly concentrated. This is presented for simple illustrative purposes only; a realistic merger analysis would have many more firms, ascribing a lower market share to each. Thus, the first blush impression that under this analysis virtually all mergers would be suspect is illusory, and made so only by the simple four firm illustration.

104. Id. The guidelines provide this example: The merging firms have shares of 5 percent and 10 percent; the HHI is increased by 100 from the merger. ( $5 \times 10$ $\mathrm{X} 2=100$ ). It explains: "In calculating the HHI before the merger, the market shares of the merging firms are squared individually: $(a)^{2}+(b)^{2}$. After the merger, the sum of those shares would be squared: $(a+b)^{2}$, which equals $a^{2}+2 a b+b^{2}$. The increase in the HHI therefore is represented by 2ab." Id.

105. Id. 7-50. This challenge will be made only after taking into account various other factors that affect the significance of market shares and concentration, like changing market conditions, financial conditions of firms in that market, and domestic or foreign firms' ability to enter or increase their presence in the market. Also, and importantly, the Department recognizes that some mergers in this rating will enhance efficiencies, thus, the parties' showing by clear and convincing evidence that a merger will achieve significant net efficiency may ameliorate this rating and reduce the likelihood of challenge. Id.

106. Id. The same factors outlined in supra note 105 are taken into consideration here. 
no violation even where these thresholds were exceeded by the merger. ${ }^{107}$ In Echlin, the top six firms in the industry accounted for $95 \%$ of sales, for a postmerger $\mathrm{HHI}$ of around 3,000 and a concentration increase as a result of the merger of around 750 points. ${ }^{108}$ In Echlin, the combination of a high $\mathrm{HHI}$ and high concentration increase was outweighed by considerations of ease of entry, with the court taking a very narrow view of barriers to entry. ${ }^{109}$ While Echlin has been noted as reflecting the Federal Trade Commission's enforcement policy under the Merger Guidelines, ${ }^{110}$ how the ease of entry analysis will be viewed against the HHI thresholds in different fact situations remains to be seen.

\section{Cross-elasticity of Product and Demand}

As noted, the ability of consumers to switch products, and the ability of other players to enter the market in response to a price increase, is the underlying economic construct of these analyses. The importance of a high $\mathrm{HHI}$ may be totally obviated if other firms can switch their production and distribution plans quickly enough to accommodate the customers that would otherwise have been harmed by a price increase.

The potential market power possessed by a group of producers functioning as a cartel is summarized by the elasticity of demand they face. Typically, the elasticity of demand facing a potential cartel increases as members of the group are placed outside the cartel. Thus, in specifying the smallest profitable cartel, the Guidelines are implicitly specifying a critical value for the elasticity of demand facing the cartel. Since economic theory predicts that the viability of a cartel is negatively correlated with the numbers of its members, focusing on the smallest profitable cartel will usually be dispositive on the likelihood of anti-competitive effects. ${ }^{111}$

107. Robert Pitofsky, New Definitions of Relevant Market and the Assault on Antitrust, 90 Colum. L. Rev. 1805, 1825 (1990) citing Re Echlin Manufacturing Co., 105 F.T.C. 410 (1985).

108. For a discussion of HHI calculations, See supra note 104 and accompanying text.

109. Pitofsky, supra note 107. The court in its formulation listed only government licenses and patents as barriers to entry. Id.

110. Id. at 1825 .

111. David Scheffman and Pablo Spiller, Geographic Market Definition Under the U.S. Department of Justice Merger Guidelines, 30 J.L. \& Econ. 123, 126 (1987). 
However, no single source exists to identify potential foreign sources of competition- either from existing firms' abilities to alter their facilities, or from new firms' potential to enter the market. Limitations on data available concerning foreign firms' capacity to devote new, revised, or increased production outputs to export to the United States make these analyses indefinite, and, perhaps unavoidably, quantitatively imprecise. Thus, qualitative assumptions about potential foreign responses must be made. In general, the Department "attempts to identify those foreign firms whose output may be relevant to the analysis, by talking to the professionals involved in the proposed merger and consulting relevant Trade Associations." 112

\section{B. Merger Control in the European Economic Community}

The EEC Merger Control Regulation (Regulation) ${ }^{113}$ which became effective in September, 1990, was implemented to satisfy the questions of conflicting applications and voids of articles 85 and 86 of the Treaty of Rome noted in part II. ${ }^{14}$ Significantly, article 2 of the Regulation provides for a one-step appraisal, whereas under article 85, two inquiries were made. The inquiry sought first to establish prohibited activity under 85(1), then to exempt the prohibition in circumstances where the activity improved the production or distribution of goods or technical progress under $85(3) .{ }^{115}$

\section{Dominant Position within the Relevant Geographic Area}

The preamble to the regulation suggests that the regulation will be applied "according to the geographical area of activity of the undertakings concerned and be limited by quantitative thresholds in order to cover those concentrations which have a Community dimension. . .."'116 Article 2(3) provides that a merger will be declared incompatible with the common market if:

112. Telephone Interview with Charles Stark, Chief of the Foreign Commerce Section, Antitrust Division, United States Department of Justice (October 18, 1991). According to Mr. Stark, the Antitrust Division is confident that persons working in the firm under evaluation can be readily relied upon to identify actual and potential, domestic and foreign competitors. Emphasis added.

113. Merger Guidelines, supta note 15. The regulation provides much of the basis for discussion in this section.

114. See supra note 39 for the full text of Art. 85; supra note 43 for the full text of art. 86.

115. Treaty of Rome, art. 85, art. 86, supra note 9 .

116. Council Regulation, supra note 46. 
the merger creates or strengthens a dominant position with the result that effective competition would be significantly impeded in the common market (or in a substantial part of it).

Within the geographic market boundaries established, a concentration meeting the certain threshold criteria will be subject to review by the Commission, and will be declared incompatible with the common market if it creates or strengthens a dominant position resulting in a significant impediment to competition. Nowhere in the Treaty or Regulation is dominance defined. As Sir Leon Brittan, Vice President of the Commission, recently expounded regarding the amorphous phrase "dominant position":

Let there be no doubt: the fundamental analysis to be carried out by the Commission is whether the merger impedes competition. A dominant position analysis, [pursuant to article 86] will be necessary in all cases in order to see whether the merged company has a sufficient degree of market power to stand in the way of competition by acting without the restraints which competition imposes in normal circumstances. . o our concern will be whether the merged company could raise prices, discriminate unfairly or restrict output with impunity or in a way which would not be possible in normal competitive conditions. ${ }^{117}$

\section{Allocation of Jurisdiction according to Turnover}

The quantitative thresholds alluded to in the preamble essentially provide a division of jurisdiction between Member States and the Commission of the European Communities, reserving to the latter jurisdiction over concentrations having a Community dimension, defined where: 1) the combined aggregate worldwide turnover of all the undertakings concerned totals more than 5,000 million ECU; ${ }^{118}$ and 2) the aggregate Community-wide turnover of each of at least two of the undertakings involved is more than 250 million ECU, unless each of the undertakings achieves more than two-thirds of its aggregate Com-

117. Sir Leon Brittan, Vice President of the Commission of the European Communities, The Law and Policy of Merger Control in the EEC, Address Before the Bar European Group, (May 3, 1990) in 15 Eur. L. Rev. 351, 352. Sir Brittan commented, "In my view, we are at the beginning of a new legal development and the Council did not wish to create a pure dominant position test." Id.

118. The E.C.U. was valued at ECU $=\$ 1.31$ in September, 1990. Cregor, supra note 4 , at 8 . 
munity-wide turnover within "one and the same Member State."119 Concentrations in this context refer to mergers and acquisitions of joint control. ${ }^{120}$

The Commission, in determining whether the proposed concentration is compatible with the common market preservation goals articulated in article 2 of the Treaty of Rome, ${ }^{121}$ will consider the structure and position of the markets concerned, including that of actual and potential competition both within and without the Community, the availability of product (or service) alternatives, ${ }^{122}$ and historical market trends. Calculations of turnover are conducted within a geographical reference market, defined as an area

[I] $\mathrm{n}$ which the undertakings concerned are involved in the supply and demand of products or services, in which the conditions of competition are sufficiently homogeneous and which can be distinguished from neighboring areas because, in particular, conditions of competition are appreciably different in those areas. This assessment should take account in particular of the nature and characteristics of the products or services concerned, of the existence of entry barriers of of (sic) consumer preferences, of appreciable differences of the undertakings' market shares between the area concerned and neighboring areas or of substantial price differences. ${ }^{123}$

Data supporting the turnover calculations are amounts derived by the involved firms' sales and services from the preceding financial year. The amounts are those after deduction of sales rebates and of taxes directly related to the turnover. ${ }^{124}$

119. Council Regulation, supra note 46, art. I. Pursuant to \3, however, these ceilings will be reviewed and possibly lowered by the end of 1993 .

120. Id. art. III.

121. Treaty of Rome, supra note 9.

122. Included in the availability analysis will be a consideration of the alternatives' access to the markets, which necessarily invokes consideration of barriers to entry. Council Regulation, supra note 46 , art. II.

123. Id. art. IX, 97.

124. Id. art. $\mathrm{V}$. Included in the calculations are the respective turnovers of (a) the undertaking concerned; (b) those undertakings in which the undertaking concerned, directly or indirectly owns more than half the assets, has the power of over half the voting rights, has power of appointment of over half the members of the controlling board, or has the right to manage the undertakings' affairs. However, sales and services as provided between these undertakings are not included in the turnover calculations. Id. 


\section{Practical Application of the EEC Merger Criteria}

A practical assessment of the Regulation's effects is made difficult due to its relative newness. However, the Regulation cannot abrogate the Treaty of Rome, as it was specifically promulgated pursuant to it, as evidenced by the recitals found at the beginning of the text. Given that the Treaty is the Constitution of the EC and thereby the preeminent authority, ${ }^{125}$ an assessment of how articles 85 and 86 have been constructed by the courts in the past is helpful to a projection of how they will be handled under the new Regulation.

The Regulation's relationship to articles 85 and 86 of the Treaty, and its effect on national authorities' sovereignty to handle internal mergers is a developing area. The three-tiered threshold recognizes implicitly that some mergers, the effects of which are confined to one member state, are better left to that state to handle; concomitantly, mergers affecting several member states are more suitably dealt with by a supranational institution. ${ }^{126}$ Recall that article 85 prohibits any agreement among undertakings that significantly restricts competition within the EEC, but provides an exception, while article 86 prohibits the abuse of a dominant position but provides for no exemptions. ${ }^{127}$ Indeed, it has been held ${ }^{128}$ that an "infringement of Article 85 can precede and thereby facilitate infringement of Article 86." 129

In addition, the Regulation expressly provides that a previously passed regulation ${ }^{130}$ regarding concentrations will not apply to concentrations as defined in article 3 of the new Regulation, echoing the 1986 Ministere Public $v$. Asjes decision. ${ }^{131}$ Ministere Public held that national courts had no authority to declare void an agreement or concerted practice under article 85 , paragraph 1 of the Treaty, as long as article 87 's requirement of implementing rules for article 85 had not been adopted. ${ }^{132}$ The upshot of this provision is to make third party challenges

125. Dassesse, supra note 37 , at 380 .

126. Brittan, supra note 117.

127. See supra notes 39 and 43 , and accompanying text.

128. Italian Flat Glass, 4 C.M.L.R. 535 (1990). (Censuring parties' formation of a cartel and preventing customers from bargaining on prices.)

129. Raybould, supra note 8 , at 190.

130. Dassesse, supra note 37, at 380, citing Council Regulation No. 17/62, O.J. Eng. Spec. Ed. 1959-62, at 87.

131. Id. at 381, citing Ministere Public v. Asjes and Others (Nouvelles Frontieres)

E. Comm. Ct. J. Rep. 1425 (1986).

132. Id. 
pursuant to article 85 , of concentrations authorized by the national control authorities, impossible. ${ }^{133}$

However, article 86 , which requires no implementing authority, ${ }^{134}$ may still be applicable even though parties are exempt under article 85, as evidenced by a recent appeal of a Commission decision in Tetra Pak. ${ }^{135}$ In that case, appellants' proposed acquisition of an exclusive license to filling equipment for liquid food products, through purchase of a company holding the license, was held to constitute an infringement of article 86, even though an exemption pursuant to article 85(3) had been granted. Although Tetra Pak had abandoned all claims to the exclusivity of the license after the Commission objected, the Commission issued the decision afterward to clarify its position. On appeal, appellants urged the Court of First Instance to hold that article 86 could not be applied to conduct which had been exempted pursuant to article 85 . Appellant relied in their argument on an earlier decision in Europemballage Corporation and Continental Can, ${ }^{136}$ which held that articles 85 and 86 could not be interpreted in a contradicting way, since they both serve to achieve the same goal. The Continental Can decision reasoned:

Articles 85 and 86 seek to achieve the same aim on different levels, viz. the maintenance of effective competition within the Common Market. The restraint of competition which is prohibited if it is the result of behavior falling under Article 85 , cannot become permissible by the fact that such behavior succeeds under the influence of a dominant undertaking and results in the merger of the undertakings concerned. .. In any case Articles 85 and 86 cannot be interpreted in such a way that they contradict each other, because they serve to achieve the same aim. ${ }^{137}$

In addition, the appellants argued that while the court in HoffmannLaRoche and Company v. E. C. Commission ${ }^{138}$ held that the operation of article 86 was not precluded if agreements fell within the ambit of

133. Dassesse, supra note 37 , at 381 .

134. Id. at 382 .

135. Id. citing Case T-51/89, Tetra Pak Rausing SA v. E.C. Commission, 4 C.M.L.R. 334 (1990) [hereinafter Tetra Pak].

136. Tetra Pak at 345 citing Case 6/72, Europemballage Corp. and Continental Can Co. v. E.C. Comm'n, E.C.R. 215, C.M.L.R. 199, 125 (1973).

137. Id.

138. Tetra Pak at 342 citing Case 85/76, Hoffman-La Roche and Co. Ag. v. E.C. Comm'n, 13 E.C.R. 461, 3 C.M.L.R. 211 (1979). 
article 85, the Hoffman court concomitantly suggested that the conduct might be saved by the exemption proviso of article 85(3). ${ }^{139}$

The Tetra Pak court was not persuaded, and invoked Article 3(f) of the Treaty of Rome, holding that the common aim of both provisionsthe institution of a system to ensure undistorted competition in the Common Market must prevail. ${ }^{140}$ Accordingly, the court held that the two provisions had to be interpreted pursuant to that objective, and that it would be sufficient for that purpose for only one provision to be applied.

Extraterritorial application of the regulation is textually implicit as well in the aggregate turnover criteria. Recall that concentrations will have "community dimensions," thus engaging the jurisdiction of the Commission, where the aggregate worldwide turnover amount is more than 5,000 million ECU and the Community-wide turnover is more than 250 million ECU. ${ }^{141}$ This language does not limit the application to mergers taking effect within the EEC territory; rather, EEC jurisdiction will be engaged if the net sales (turnover) are sufficiently high on a global and community scale. "By this test, the Community apparently claims jurisdiction over operations which have significant effects in the Community: any concentration between two undertakings situated outside the Community which meet the ECU five billion test and which have ECU 250 million turnover in the Community will. . . require notification." ${ }_{142}$

Indeed, in 1988 in Alstrom v. Commission (Wood Pulp), ${ }^{143}$ it was made clear that concentrations located entirely outside the territory of the EEC can have an EEC dimension and thus invoke the jurisdiction of the Community. ${ }^{144}$ While it is clear that the Regulation is concerned only with effective competition within the Community, ${ }^{145}$ it is equally clear that competition may be affected by activities conducted entirely

139. Id.

140. Tetra Pak at 445.

141. See supra note 113 and accompanying text for relative U.S. valuation.

142. Christopher Jones, The Scope of Application of the Merger Regulation, INTERnational Mergers and Joint Ventures, Fordham Corp. L. Inst. 385, 387. (B. Hawk, ed., 1990).

143. Alstrom v. Commission, E. Comm. Ct. J. Rep. 5193, 1985 O.J. (L 85/ 1).

144. Id.

145. Bernd Langeheine, Substantive Review Under the EEC Merger Regulation, INternational Mergers and Joint Ventures, Fordham Corp. L. Inst., 481, 493. (B. Hawk, ed., 1990). 
outside of the EEC, where the threshold criteria and abuse of dominant position test are met.

\section{Comparative Analysis}

The willingness of courts both in the United States and the EEC to assert jurisdiction to activity occurring outside the boundaries of their domestic territories makes imperative an understanding of how the substantive review criteria employed in each of the regulations concur and diverge.

The general tenor of both the EEC Merger Regulation (regulation) and the U.S. Merger Guidelines (guidelines) are the same: consumers are best protected when producers vying for their dollars have to compete for them. Both instruments attempt to gauge the merger's future effect on the domestic market by evaluating underlying, and largely historic, economic indicators. Thus, in both approaches the accuracy of predictions of future market reactions depends on the accuracy of the data built into the economic formulae as well as the validity of the models' assumption: that past activity is an accurate indicator of future behavior. Unfortunately for this discussion, nothing in the literature suggests that merger control decisions (whether to challenge or leave intact) are routinely inserted back into the formulae, after sufficient passage of time, to check the accuracy of the assumptions or the model supporting the decision. Nonetheless, underlying premises of the two models are, at least in concept, in accord.

Likewise, the data supporting the analyses are similar. The Merger Guidelines instruct that specific sales, import-export trends, market trends, and historical pricing trends in the respective industry will be evaluated to infer likely competitive effects of the merger. The Merger Regulations also specify that the sales volumes, pricing trends, importexport figures, and historical pricing indices will be taken into account in assessing the impact of the merger. Both attempt to take into account the ability of firms not then competing in the relevant market to enter the market, either through adjustments to then extant production facilities or through the creation of new production facilities.

The numeric thresholds employed in each regulation are, however, different both in the mathematical relationships reflected and in the purpose behind the exercise. Regarding the relationships reflected, under the U.S. guidelines, the Hershman-Hinderfahl Index reflects total market concentration, taking into account all those products which are similar enough to function as product substitutes in the event of a price increase, and limiting the inquiry to the geographic region deemed most reflective of the true market, be it a portion of a city or the 
entire world. The index is essentially a test of market concentration. Both the existing concentration levels and the increase in the concentration levels resulting from the merger are employed in the analysis, which is supported by the proposition that the more highly concentrated the market already is, and the more the merger increases that concentration level, the more readily a hypothetical firm could manipulate the market and raise prices.

In contrast, the numerical threshold employed by the EEC Merger Regulations takes no account of shares of market presented by the parties to the merger. Rather, the turnover criteria provided in the regulation take an overall measurement of sales or services provided in the preceding year by the firms in question, again after taking steps to insure that those companies competing in the market are accounted for in the analysis. Here the assumption is largely parallel to the U.S. counterpart: the larger the firms' shares in the market under evaluation, the more ability those firms will have to exercise their market power and raise prices at the expense of the consumer. However, the regulation is based on an outright measurement of the market activity without regard to concentration levels. A finding that the firms involved produced the requisite turnover the preceding year will invoke the jurisdiction of the Commission, regardless of the degree to which that market is concentrated. So, the measurements employed by the two jurisdictions vary in this way: the U.S. index reflects a measurement of market concentration, while the EEC thresholds reflect a quantitative measurement of market activity.

The purposes for which the respective threshold levels are used are fundamentally different as well. In the United States, the HHI is used primarily as an indicator, after weighing other factors regarding whether the merger is likely substantially to lessen competition, of the probability that the merger will be challenged. In contrast, the turnover thresholds provided in the EEC's guidelines were conceived as a way to allocate merger regulation jurisdiction between the authorities of the member states and the EEC Commission. Simply stated, a low turnover or a community-wide turnover which is confined primarily to the boundaries of a single member state will be regulated by that member state.

Perhaps the most substantive comparison is that of the concept used to express the likelihood that the merger will have undesirable effects on competition. In the United States, the HHI and all the other considerations discussed are tools of inquiry to answer this question: Will this merger threaten competition? Inherent in that question is the subquestion, "could a 'monopolist' profitably impose a small but sig- 
nificant and nontransitory price increase?" If the answer is yes and the requisite HHI level is met, the merger is likely to be challenged. In the EEC, the turnover thresholds and the other considerations taken into account in the merger analysis are employed to answer: Will this merger impede competition? The subquestion here is whether the merging firms hold a sufficiently dominant position in the market that they could engage in restrictive behavior. Fundamental to both inquiries is an assessment of whether enough market power is present to enable the firm to exploit consumers; the semantic differences notwithstanding, the concepts underlying the substantive goals are the same.

\section{Conclusion}

Because international mergers are common and likely to become more so, an understanding of where the two approaches agree and diverge is important not only to business operating in the international sphere but to negotiators embarking on a treaty that could dramatically change the way international mergers are conducted. While application of both regulations involves complexities and a Herculean assessment of what could happen given a hypothetical merger, the United States' guidelines are perhaps more sophisticated. This may be attributed to the relative maturity of the U.S. antitrust system, as well as to a function of the EEC Regulation that is entirely missing from the U.S. Guidelines: a division of jurisdiction over mergers. The three-tiered turnover threshold of the EEC's regulation represents not a likelihood of challenge of the merger, as provided in the U.S. HHI, but an indication of which authority - that of the member state or that of the European Commission-will preside over any challenge to the merger.

Even though there are quantitative differences between the two approaches, the spirit is the same: to apprehend those mergers which, due to significant market power presented by the merger, may be able to exert enough influence on the market to impede free competition. Given that any bilateral agreement between the EEC and the United States is not likely to succeed if it attempts to unravel what is on both sides the culmination of years of internal debate, it behooves convention negotiators to come to the table well versed in the nuances reflected in merger policies of both sides.

\section{Discovery Problems in International Antitrust ENFORCEMENT}

As alluded to in Part III, collecting specific information regarding internal production capabilities and marketing strategies of companies 
is preliminary homework to an investigation of a proposed merger involving those companies or their competitors. However, in an international context, companies located abroad are sometimes reluctant to comply with discovery information requests of foreign origin. This section will highlight some of the problems existing in international merger control with respect to obtaining information necessary to conduct a merger analysis, and will examine the need for an agreement in this area between the United States and the European Community.

Foreign discovery conducted by the United States pursuant to antitrust statutes, whether through the government or private parties, has caused conflicts for some time. ${ }^{146}$ Specifically, several foreign governments have invoked commercial secrecy laws or adopted blocking statutes in response to American antitrust discovery. These statutes bar foreign discovery by either controlling or prohibiting companies located within their territory from complying with information requests of foreign enforcement authorities or courts. In 1980 France enacted a statute imposing criminal liability, subject to an exception provided under international treaties, on any foreign national seeking discovery in connection with foreign judicial or administrative proceedings; ${ }^{147}$ the United Kingdom enacted the Protection of Trading Interest Act in $1980 ; ;^{148}$ and Switzerland specifically forbids the transmission of or attempt to obtain a manufacturing or business secret in order to make it available to a foreign private or official body, to name a few such statutes. ${ }^{149}$

Because some foreign governments view subpoenas as an intrusion and, worse, an infringement of their sovereignty, the Bureau of Competition of the Federal Trade Commission strives to seek only that information which cannot be obtained domestically. Voluntary cooperation is the preferred avenue for obtaining information and evidence located abroad. However, "[the Bureau's] experience has not been trouble-free. Foreign discovery has caused delays and occasionally complicated investigations and adjudicative procedures. . . subpeonas for testimony of foreign nationals or for documents located abroad continue, on occasion, to generate strong objections, and have resulted in motions to quash."'150 Those motions to quash contest the Commission's exercise

146. Hearings, supra note 1 , at 8 (statement of Kevin J. Arquit, Director, Bureau of Competition, Federal Trade Commission).

147. Id. at 14, n. $6,7,8$.

148. Id. at 15, n. 7 .

149. See fn. 148, n. 8 .

150. Id. 
of personal jurisdiction and its method of service of process. While one tool at the Commission's disposal is to issue subpeonas to the foreign corporation and serve process on the firm's American subsidiary, these avenues are time-consuming and are said to highlight the Commission's difficulty in effecting extraterritorial service directly on foreign firms and foreign nationals. ${ }^{151}$ In sum, the appropriate procedure for obtaining foreign discovery in countries with commercial secrecy laws is not yet certain.

\section{A. Organization for Economic Cooperation and Development}

The U.S. antitrust enforcement agencies have entered into agreements with foreign authorities in an effort to ameliorate some of these discovery problems. These voluntary bilateral and multilateral agreements, whose terms cover discovery procedures, provide for prior notification, consultation, and cooperation in antitrust enforcement actions which could affect foreign interests. No country which is a party to such an agreement has invoked a blocking statute since entering into the agreement. ${ }^{152}$ The multilateral agreements have been in existence for some time, having first been issued in 1967, and revised in 1973, and 1979. ${ }^{153}$ The agreements are currently under the Organization for Economic Cooperation and Development (OECD), adopted by the Council of the OECD on May 21, 1986. ${ }^{154}$ The current OECD agreement specifies that competition agencies notify foreign party states, if at all possible, in advance of taking any action which could affect interests of those states. The latest version also includes an appendix containing guiding principles on restrictive business practices which affect international trade, providing for notifications, exchanges of information, and consultation recommendations. ${ }^{155}$ Also included are guidelines for conciliation between states who are unable to agree on a particular matter, and the provision of the use of the Committee on Competition Law and Policy. ${ }^{156}$

151. Id. at 18 .

152. Id. at 16 .

153. Edward F. Glynn, Jr., International Agreements to Allocate Jurisdiction Over Mergers, International Mergers and Joint Ventures, Fordham Corp. L. Inst 35 , 38 (B. Hawk, ed., 1990).

154. Id.

155. Id. at 38 .

156. Id. To date, there is no public record of any members having taken advantage of the office of the Committee to settle disputes. Id. at 39 . 
The OECD agreement, multilateral in nature, is different from existing bilateral agreements. Currently, the United States is party to only one bilateral agreement with a European Community stateGermany ${ }^{157}$ - while both the United States and the EEC are parties to the 1986 OECD Recommendation. What is unclear, however, is how such bilateral agreements of the future will be affected by the Treaty of Rome and the Merger Regulation discussed herein. Given the thresholds providing exclusive jurisdiction of some mergers with the European Commission rather than the enforcement agencies of member states, it is likely that notification requirements under existing bilateral agreements will cede to a future agreement between the United States and the EEC. This is necessarily so under the Merger Regulation, because if member states' jurisdiction to review mergers is vested with the Commission after a certain monetary threshold is met, it follows that procedures pursuant to the merger review will vest with the Commission as well. The extent to which the Commission will proceed to comply with information agreements entered into by individual member states and nonmember states is at present unknown.

In addition, the existing agreements provide for consultation and notification under a "quasi-adversarial" scheme. ${ }^{158}$ When one party who is in charge of investigating or prosecuting antitrust breaches submits a notification, it will typically be submitted not to that country's antitrust enforcement agency but to its commercial or foreign affairs ministry. That is because the "protective interests" in the nation's own commercial, economic or legal interests generally fall under a different organ than that country's antitrust enforcement agency. For this reason, the EEC itself rarely if ever receives the notification from an investigating OECD member. Rather, because these protective interests rest primarily with the national member states of the EEC, the commercial ministry of the country where the involved company is located receives the notice. "There is, in short, no 'protective interest,' at least under existing rules, that would trigger an obligation to notify by the United States. The notification of proposed investigation or enforcement action goes not to the Community but to the national authority." 159

157. Id. at 37, citing Bilateral Agreement with the Federal Republic of Germany, reprinted in 4 Trade Reg. Rep. (CCH) $\$ 13,501$.

158. Id. at 42 .

159. Id. at 45 . 


\section{B. Hart-Scott-Rodino}

As mentioned in Part II, the Hart-Scott-Rodino (HSR) Act ${ }^{160}$ provides assistance in merger and acquisition discovery procedures. Pursuant to HSR, parties to mergers amounting to certain dollar levels are required to give notice in advance to the Federal Trade Commission, and to wait a specified period before proceeding with the merger. Given foreign firms' desire to conduct business in the United States, their cooperation with this procedure has been good. As noted before a Senate hearing on the matter, "[i]n general, foreign governments perceive the HSR filing requirements as a legitimate prerequisite to any foreign firms wishing to make an acquisition affecting the U.S. market. Because parties cannot complete their deal without submission of the appropriate material, they have strong incentives to comply with requests for information." 161 However, difficulties in obtaining all the necessary information pursuant to the merger analysis persist due to foreign discovery problems encountered when seeking to complete documents supplied domestically with sources located abroad. ${ }^{162}$

A larger problem in HSR discovery, alluded to in Part III, is that of obtaining information from third parties to the merger. Recall the discussion of market and production elasticity, and the importance of projecting not only how consumers would respond to a price increase, but how other firms would respond. Some firms which are totally out of the computations of market share and competition might find it profitable to either alter or switch production facilities entirely in order to enter the market following such a price increase. While third parties are routinely surveyed for information about market shares and ease of entry, ${ }^{163}$ these firms usually have an interest adverse to the acquisition, and so have no incentive to help the merger be accomplished quickly. As explained, "[f]oreign competitors may view as overly intrusive discovery requests for sales and production information, including future plans; such data is often needed in merger investigations to define the relevant market in which to predict competitive effects." 164

160. Hart-Scott-Rodino Act of 1975,15 U.S.C. $\$ 18($ a), Pub. L. No. 101-73, 103 Stat. 529 (1989).

161. Arquit, supra note 146 , at 19.

162. Id. at 20. "However, as with the substantive response, it is difficult to prove a negative: that relevant documents were omitted from the submission." Id. $\mathrm{n}$. 13.

163. Id. at 21 .

164. Id. In these cases, the Commission resorts to subpoena enforcement pro- 
As a final note, it may help in the analysis to understand some of the practical requirements involved in complying with merger enforcement regulations in both the United States and the EEC. First, both jurisdictions require that certain plans to merge be made known to the reviewing authority before the merger takes place. In the EEC, a merger with a Community dimension must be notified not more than one week after the conclusion of the agreement, the announcement of the public bid, or the acquisition of a controlling interest, whichever is earlier. ${ }^{165}$ In the United States, a thirty-day waiting period exists before the acquisition can take place. The United States provides for time extensions; the EEC does not. Both entities require that a standard form be used in the pre-notification, and the volume of information required on the forms makes it prudent to start collecting the necessary data well in advance of the deadline. ${ }^{166}$

With respect to confidentiality, in the United States, pre-merger notification filings may not be made public, unless relevant to administrative or judicial actions. Disclosure can also be made to Congress. ${ }^{167}$ In the EEC, professional secrecy rules dictate that information received can only be used for purposes related to the request, investigation, or hearing. The Commission has to provide copies of all notifications to authorities of the member states, and must publish the fact of notification (where the merger falls under the scope of the Regulation). Included in that publication are the names of the parties, nature of the merger, and the economic sector involved. However, the publication must take into account the legitimate professional secrecy interests of the undertakings involved. ${ }^{168}$

\section{Information Agreements in the Competition Area: Possible Approaches}

An understanding of some of the problems encountered in antitrust foreign discovery efforts, and an overview of what pre-merger filing requirements exist in the United States and EEC, permits now a look

ceedings in federal district court, sometimes taking months before the order is issued. Id.

165. J. William Rowly, International Mergers: Antitrust Notification Requirements, INternational Mergers and Joint Ventures, Fordham Corp. L. Inst. 221, 236 (B. Hawk, ed., 1990), previewing Rowly, International Mergers-Antitrust Guide (Sweet \& Maxwell, eds.).

166. Id. at $236,265$.

167. Id. at 268 citing 15 U.S.C. $\$ 18(\mathrm{a})(\mathrm{h})$.

168. Id. at 240 . 
at some of the options which could afford greater cooperation in this area between the United States and the EEC.

Perhaps at the modest end of the scale, competition authorities involved might explore how to improve their communication among themselves. ${ }^{169}$ This may help alleviate the anomalous reality mentioned above where the dialogue exists between the competition authority of one state and the commerce ministry of the other under the "protective interest" analysis. However, the Justice Department has noted,

[t]he amount of information that can be shared among authorities is severely limited by confidentiality provisions in our respective national laws. Accordingly, if much additional information is to be shared by the various merger control authorities, the types of information sought to be exchanged would have to be identified with some specificity, and national laws would have to be amended. ${ }^{170}$

An assessment of the various confidentiality laws extant in members of the EEC, and the relationship of those laws to the Merger Regulation and ultimately to the Treaty of Rome, would require analysis of sensitive member state sovereignty issues; while worthy of exploration, this is clearly beyond the scope of this discussion.

Another option presented is to rely more heavily on obtaining foreign information from parties other than the competition authorities, while at the same time seeking an agreement among competition authorities to help their foreign counterparts by producing locally held information. ${ }^{171}$ Again, however, this appears to beg the question, for ultimately the information comes not from foreign antitrust authorities but from parties outside the merger agreement. This is obviously so in terms of relying on third party information to evaluate elasticities.

Proposals for information sharing agreements pursuant to competition regulation have not been one-sided. Preeminent in this discussion must be the recent United States-EEC antitrust cooperation proposal by European Commission Vice President Sir Leon Brittan. In a speech at Cambridge University, Sir Brittan said:

I personally favour, to start with, a treaty between the European Community and the U.S.A. It would provide for con-

169. Charles Stark, International Mergers and Joint Ventures: A View from the Justice Department, International Mergers and Joint Ventures, Fordham Corp. L. Inst., 21, 31 (B. Hawk, ed., 1990).

170. Id.

171. Id. 
sultations, exchanges of non-confidential information, mutual assistance, and best endeavours to cooperate in enforcement where policies coincide and to resolve disputes where they do not. Disagreements should be discussed frankly and, wherever possible, only one party should exercise jurisdiction over the same set of facts. ${ }^{172}$

While this language imparts greater purpose to the agreement than the exchange of notifications and consultations under OECD and the bilateral agreements discussed above, it is clear that a prominent feature of any US/EEC bilateral agreement in the area of antitrust must include information sharing provisions.

It could be that with the passage of time, parties will perceive their notification and consultation needs met through existing channels of the OECD agreement. However, as already discussed, information from third parties remains a critical issue, as they, not the parties to the transaction, have "the most reliable evidence on entry barriers, the ability of customers to substitute, and ability of foreign parties to enter the market in response to a price increase and other matters which drive the elasticity analysis." ${ }^{173}$ Elasticity concerns are not confined to analyses under the U.S. Merger Guidelines; as noted in part I, article 2 of the EEC's Merger Regulation requires the European Commission to factor in "the structure of all the markets concerned and the actual or potential competition from undertakings located either within or (outside of) the Community." ${ }_{174}$ Specifically, the Commission is to consider the market positions of the firms concerned, the alternatives available to suppliers and users, their access to supplies or markets, and any barriers to entry in assessing whether the proposed merger is compatible with the Common Market. ${ }^{175}$

One approach recommended to establish a ready supply of third party information to foreign discovery requests is that of an international convention providing for mutual provision of product and market information sought by foreign authorities. ${ }^{176}$ Again, however, given the passage of time this approach may duplicate provisions under the

172. GLynn, supra note 153, at 44, citing Jurisdictional Issues in EEC Competition Law, Address by the Right Honorable Sir Leon Brittan, Hersch Lauterpacht Memorial Lecture, Cambridge University (February 8, 1990).

173. Id. citing Glynn \& Tahyar, Obtaining Data on Elasticities and Foreign Competitors under Hart-Scott-Rodino, 1988 Fordham Corp. L. INST. 3-1 (B. Hawk, ed., 1989).

174. Council Regulation, art. II, supra note 46.

175. Id.

176. GLYNN, supra note 153 , at 48 . 
OECD. It may be possible to simply amend the OECD to bring third parties to mergers under the proposal, and to provide that data from those firms routinely will be made available to requests from other member states.

Ancillary to these proposals is a review of the procedures under which results of antitrust investigations are reported to the public. The factors supporting a competition authority's decision in individual merger cases, thumbs up or down, should be made available to to help guide involved parties' future conduct. In this arena, there is room for improvement within the United States, as explained thusly in a panel on international mergers and joint ventures:

If (the Department of Justice or the Federal Trade Commission) elects not to challenge a transaction, there will be no complaint and no published opinion, and the basis on which (they) elected to bring a challenge will typically be known only to (them), and to some extent, to the lawyers and economists for the merging parties who participated in persuading (them) not to bring the action. On the other hand, if the (Department of Justice or the Federal Trade Commission elects) to challenge a transaction, in most instances the parties will call off the transaction. ${ }^{177}$

This shroud of secrecy is a side effect of the unique nature of merger control in the United States, as explained in Part II. Because of the court's limited role in merger reviews, the reviews generate relatively few judicial opinions. While there may be indirect ways of learning what factors drove the decisions to challenge or leave intact the proposed mergers, "[I]n the final analysis, while the main instrument of merger policy in the United States is the agency's decision whether or not to prosecute, there is no regular mechanism for reporting the analysis that underlies such a decision." 178 Even though none of the proposals reviewed calls for the uniform sharing of factors that underlie enforcement decisions, it is a safe bet that parties to the agreement who provide information will want to witness the use of that information when it produces a result adverse to the providing parties' interests.

Whether any of these proposals or conventions could serve as a catalyst for an international commerce ministry is unknown. Such a

177. George Hay, Panel Discussion: International Mergets and Joint Ventures, INternational Mergers and Joint Ventures, Fordham Corp. L. Inst., 95, 97 (B. Hawk, ed., 1990).

178. Id. 
ministry could be responsible for documenting production facilities of all firms located in party states, and could serve as a central repository for import-export data. In addition, depending on the sophistication and level of automation of such a ministry, a data base built on international product characteristics and consumer profiles could be maintained. If market prices and trends are built into the data base, it should be possible to quantify product elasticity to project international market responses in a more standardized fashion. Indeed, the development of such a data base would lend itself greatly to an after-thefact analysis of the effects of merger decisions, an exercise not routinely performed now, as mentioned earlier. Given limitations on domestic data sources, however, it may be difficult to conceive of how such a model could be built in an international setting, accommodating differing languages, different units of measurement, differing currencies, and qualitatively different consumer cultures. Nonetheless, it is convincing that since market and product data are at the core of merger analyses, the trend in the future will be away from ad-hoc assessments of elasticity, which take into account whatever information happens to be available, and toward uniform, international assessments driven by sophisticated and well maintained data bases.

\section{Conclusion}

It is clear that both the United States and the European Community recognize that anticompetitive activity abroad can profoundly affect domestic economies. As a result, there is authority on both sides to apply domestic antitrust regulations to foreign activity. Under international law, countries exercise jurisdiction only when sufficient effects within the acting state are felt from the activity under review. As a principle of comity, as well, states will respect the sovereignty of other nations and refrain from exercising jurisdiction under certain circumstances. As shown, however, neither of these principles is adequate for addressing which state should exercise antitrust enforcement where grounds for asserting jurisdiction are equally divided.

In analyses conducted under both the EEC Merger Regulation and the U.S. Merger Guidelines, it is clear that markets and suppliers of firms are becoming increasingly international in nature. Thus, the likelihood that merger reviews conducted internally will focus on factors located outside domestic boundaries is increasing. It is clear that before jurisdiction can be allocated, sufficient discovery must be conducted to see where the predominant acts and effects take place. Likewise, substantive review relies entirely on the accuracy of the data utilized in computing market share, geographic markets, product profiles, and 
market elasticity. Especially in the latter category, it is critical that data from foreign firms, often third parties to the merger under review, be obtained. The difficulty experienced in procuring these data from foreign sources underscores the necessity for a bilateral agreement to cooperate, (or at minimum not obstruct through blocking statutes) in antitrust investigations. It is hoped that, through the exploration of the complexities involved in international regulatory schemes, skepticism about the possibilities of an agreement have been preempted by an understanding of the need to agree, if on nothing else than to agree, before 1993 arrives.

Sabrina Haake*

- J.D. Candidate, 1993, Indiana University School of Law-Indianapolis. 
